\title{
Preliminary results on associations between leptin gene $(L E P)$ and some reproduction performance traits of boars
}

\begin{abstract}
Summary
Studies on porcine genome contributed to identification of polymorphic loci of the genes that may influence the level of reproduction-related traits. The LEP gene codes for leptin - a protein secreted to blood from adipocytes, important for food intake, energy expenditure, and immune response; the protein also influences some functions of mammalian reproductive system. The aim of this study was to determine the polymorphism of HinfI in the leptin gene and its effect on selected qualitative and quantitative traits of the semen. The analyses included 54 AI boars, which had been derived from crossing Duroc with Pietrain breeds. The genotypes were established with PCR-RFLP. Two alleles $L E P / H i n f$ I were identified: $L E P^{\mathrm{T}}(152 \mathrm{bp})$ and $L E P^{\mathrm{C}}(68$ and $84 \mathrm{bp})$ with the frequencies 0.713 and 0.287 respectively. The genotype frequencies were as follows: $L E P^{\mathrm{T}} L E P^{\mathrm{T}}-0.5185, L E P^{\mathrm{T}} L E P^{\mathrm{C}}-$ $0.3889, L E P^{\mathrm{C}} L E P^{\mathrm{C}}-0.0926$. The results obtained here demonstrated significant $(\mathrm{P} \leq 0.05$ and $\mathrm{P} \leq 0.01)$ predominance of $L E P^{\mathrm{C}} L E P^{\mathrm{T}}$ and $L E P^{\mathrm{T}} L E P^{\mathrm{T}}$ boars in respect to ejaculate volume, percentage and number of live sperms and concentration of sperms.
\end{abstract}

Key Words: Sus scrofa, boars, leptin gene, LEP, semen characters

\section{Zusammenfassung}

Titel der Arbeit: Erste Ergebnisse von Zusammenhängen zwischen den Polymorphismen im Leptingen und ausgewählten Merkmalen der Reproduktionsleistung von Ebern

Genomuntersuchungen beim Schwein haben zur Identifikation von polymorphischen Loci der Gene, die einen Einfluss auf die mit der Reproduktion verbundenen Merkmalen haben können, beigetragen. Das Leptingen, dessen Produkt, Leptin, hauptsächlich durch Fettzellen ins Blut abgegeben wird, spielt eine wichtige Rolle u.a. bei Futteraufnahme, Energieverbrauch, Immunantwort und wirkt auf einige Funktionen des Reproduktionssystems der Säugetiere ein. Das Ziel der Unterschungen war die Bestimmung des Polymorphismus von Hinfl im Leptingen sowie seinen Einfluss auf ausgewählte quantitative und qualitative Merkmale des Eberspermas. Es wurde ein Kollektiv von 54 Zuchtebern aus der Kreuzung der Rassen Duroc und Pietrain untersucht. Zur Genotypbestimmung wurde die PCR-RFLP eingesetzt. Es wurden zwei Allele LEP/HinfI, LEP ${ }^{T}(152$ Basenpaare) sowie $L E P^{\mathrm{C}}$ (68 Basenpaare), mit einer Frequenz von entsprechend 0,713 und 0,287 identifiziert. Die Genotypfrequenz lag auf folgendem Niveau: $L E P^{\mathrm{T}} L E P^{\mathrm{T}}-0,5185, L E P^{\mathrm{T}} L E P^{\mathrm{C}}-0,3889, L E P^{\mathrm{C}} L E P^{\mathrm{C}}-$ 0,0926. Die ermittelten Ergebnisse wiesen eine signifikante $(P \leq 0,05$ und $P \leq 0,01)$ Überlegenheit der Eber mit den Genotypen $L E P^{\mathrm{C}} L E P^{\mathrm{T}}$ und $L E P^{\mathrm{T}} L E P^{\mathrm{T}}$ hinsichtlich des Ejakulatvolumens, des Anteils und der Anzahl lebender Spermien und der Spermakonzentration auf.

Schlüsselwörter: Sus scrofa, Eber, Leptingen (LEP), Spermamerkmale

\section{Introduction}

The studies on porcine genome contributed to identification of polymorphic loci of the genes that may influence the level of reproduction-related traits. It has been suggested that the leptin gene may have such function.

Leptin, coded by the LEP gene, is a polypeptide hormone (ZHANG et al., 1994) with a molecular weight of $18.661 \mathrm{kDa}$ in pigs (BIDWELL et al., 1997). It is secreted to blood mainly from adipocytes (ZHANG et al., 1994; BIDWELL et al., 1997). 
Leptin is an important factor mainly in regulation of food intake and energy expenditure (RENTSCH et al., 1995; PELLEYMOUNTER et al., 1995). The localisation of leptin receptors in ovaries, testes, uterus (BARASH et al., 1996; LIN et al., 2000), and hypothalamus (TARTAGLIA, 1997) indicates that leptin may act in various regions of the reproductive system, which in turn implies that the protein takes part in the reproductive functions (BARASH et al., 1996).

The leptin gene was mapped to porcine chromosome 18 (NEUENSCHWANDER et al., 1996; SASAKI et al., 1996) and is highly conserved in a number of mammalian species (RAMSAY et al., 1997). The gene expression is regulated by adipose tissue mass and hormones, such as insulin, glucocorticoids (HOUSEKNECHT and PORTOCARRERO, 1998), estrogens (SHIMIZU et al., 1997), prolactin (GUALILLO et al., 1999), testosterone (BLACHE et al., 2000), and GH (HOUSEKNECHT et al., 2000).

In pigs, the gene is expressed in the adipose tissue as 3.100bp mRNA (BIDWELL et al., 1997). A higher level of leptin mRNA was found in subcutaneous adipose tissue of finished pigs $(136 \mathrm{~kg})$ than that in those still growing $(60 \mathrm{~kg})$ (BIDWELL et al., 1997). By approximately $306 \%$ higher level of leptin mRNA and the protein alone was found in the plasma of obese pigs in relation to the non-obese pigs of the same body weight (RAMSAY et al., 1998). The levels of expression differed also between the regions of adipose tissue. In pigs, these were higher in subcutaneous adipose tissue than in that of omental and retroperitoneal regions, wereas in cattle, the highest expression levels of mRNA were found in perirenal adipose tissue, lower in subcutaneous tissue, and the lowest in mesentheric tissue (XIE et al., 1999).

Several single base polymorphisms were found in the porcine leptin gene: substitutions $\mathrm{C} / \mathrm{T}, \mathrm{A} / \mathrm{G}, \mathrm{C} / \mathrm{T}, \mathrm{G} / \mathrm{T}, \mathrm{A} / \mathrm{T}, \mathrm{T} / \mathrm{C}$ and $\mathrm{G} / \mathrm{A}$ at the positions, respectively, 867, 1112, 3469, 3714, 2845, 3996 and 2728 (STRATIL et al., 1997; JIANG and GIBSON, 1999; KENNES et al., 2001).

A realtionship was found between the C/T (3469) polymorphism and the carcass leannes as well as the daily gain of Polish Landrace pigs. The values of these traits were statistically significantly higher in TC individuals compared with TT homozygotes (KULIG et al., 2001). However, different results were reported by KENNES et al., 2001, for the Landrace breed. Higher daily weight gain was characteristic for the TT pigs compared with the AA homozygotes. JIANG et al. (1999) reported an association between this polymorphism and fatness in the Large White breed. Also, an association was revealed between the A/T (2845) polymorphism and total feed intake and average estimated breeding values for age (adjusted to 100 $\mathrm{kg}$ ) in the Landrace breed. The above traits were higher in the TT individuals compared with the AA homozygotes. The lack of association between the mentioned traits and polymorphisms in the leptin gene in the other breeds (Duroc, Yorkshire, Hampshire) suggests that linkage disequilibrium is characteristic for Landrace and Large White breeds.

Also significant polymorphic associations were found between the 2nd intron (ZWIERZCHOWSKI et al., 2001), as well as the 2nd exon (BUCHANAN et al., 2002) of bovine leptin gene, and carcass traits. LIEFERS et al. (2002) found that these polymorphisms are associated with milk performance traits.

No information was found about how the leptin gene polymorphisms influence the reproductive traits in pigs. 
Following the above data and suggestions, we undertook the studies aimed to determine Hinfl polymorphisms in the leptin gene locus of AI boars, and we attempted to establish possible association between the LEP genotypes and some qualitative and quantitative characters of porcine semen.

\section{Material and methods}

The analyses comprised 54 Duroc x Pietrain boars utilised at an Artificial Insemination Station.

The DNA was isolated from blood collected into vacuum tubes, with $\mathrm{K}_{3}$ EDTA added as anticoagulant. The isolation was carried out with MasterPure kit (Epicentre Technologies).

Leptin genotypes were analysed using PCR-RFLP. DNA fragment of 152 bp was amplified with the following primer sequences, given by NEUENSCHWANDER et al. (1996): forward primer: 5'-TGC AGT CTG TCT CCT CCA AA-3' and the reverse primer: 5'-CGA TAA TTG GAT CAC ATT TCT G-3'. The PCR was performed in a volume of $20 \mu \mathrm{l}$ containing 70-100 ng DNA, PCR buffer, $0.75 \mathrm{mmol}$ of $\mathrm{MgCl}_{2}, 10$ pmol of each nucleotide, 25 pmol of each primer, and $0.5 \mathrm{U}$ of Taq polymerase. The PCR conditions were as follows: $94^{\circ} \mathrm{C}$ for 3 min.; 30 cycles for 1 minute each at $94^{\circ} \mathrm{C}$, $58^{\circ} \mathrm{C}$, and $72^{\circ} \mathrm{C}$; the final synthesis at $72^{\circ} \mathrm{C}$ for $5 \mathrm{~min}$.

The PCR product was digested with 3 units of Hinfl restrictive endonuclease at $37^{\circ} \mathrm{C}$ for 3 hours, and then separated on $2.5-3 \%$ agarose gel stained with ethidium bromide. After the electrophoresis, the gels were analysed in UV.

We analysed relationships between the polymorphism in the LEP/Hinfl gene and ejaculate volume $\left(\mathrm{cm}^{3}\right)$, ejaculate sperm concentration $\left(\mathrm{mln} / \mathrm{cm}^{3}\right)$, percentage of live sperms, number of live sperms in ejaculate $\left(10^{9}\right)$, number of insemination doses, and the age of the boars at the moment of ejaculate collection, despite the fact that the ejaculates were collected from the boars at age range 221-420 days only. The minimum number of ejaculates per an individual boar was 6 , while the maximum number was 45 , with the mean 21.6 ejaculates.

The semen data were collected from ejaculates sampled and evaluated between 19 March 1998 and 31 Oct. 2001, and referred to ejaculate volume $\left(\mathrm{cm}^{3}\right)$, sperm concentration (million $/ \mathrm{cm}^{3}$ ), percentage of live sperms, number of live sperms per ejaculate $\left(10^{9}\right)$, number of spermatozoa per insemination dose [billion], and the number of obtained doses. In order to eliminate the effect age, only 1015 ejaculates collected from the boars at the age of 221-420 days were used in the analysis. The sampling year was divided into two seasons:

I -1 March -30 Sept. (spring-summer)

II - 1 Oct. -29 Feb. (autumn-winter).

Statistical analysis of qualitative characters in relation to LEP genotype was carried out with least-square multiple variance analysis (HARVEY, 1987) according to the following model:

$$
\mathrm{Y}_{\mathrm{ijk}}=\mu+\mathrm{a}_{\mathrm{i}}+\mathrm{b}_{\mathrm{j}}+\mathrm{c}_{\mathrm{k}}+(\mathrm{ab})_{\mathrm{ij}}+(\mathrm{ac})_{\mathrm{ik}}+(\mathrm{bc})_{\mathrm{jk}}+\mathrm{e}_{\mathrm{ijk} \mathrm{k}}
$$

where:

$\mathrm{Y}_{\mathrm{ijk}}$ - value of the character for the i-th LEP genotype, $\mathrm{j}$-th year, and k-th season;

$\mu$-population mean 
$\mathrm{a}_{\mathrm{i}}$ - constant effect of the $\mathrm{i}$-th $L E P$ genotype $(\mathrm{i}=1,2,3)$;

$b_{j}$ - constant effect of the $j$-th year $(j=1,2, \ldots, 4)$;

$\mathrm{c}_{\mathrm{k}}-$ constant effect of the $\mathrm{k}$-th season $(\mathrm{k}=1,2)$;

$(\mathrm{ab})_{\mathrm{ij}}$ - effect of interaction $L E P$ genotype $\mathrm{x}$ year;

$(\mathrm{ac})_{\mathrm{ik}}$ - effect of interaction LEP genotype $\mathrm{x}$ season;

$(b c)_{j k}-$ effect of interaction year $\mathrm{x}$ season;

$\mathrm{e}_{\mathrm{ijk} 1}$ - error.

The values of the studied traits were expressed as the means and their standard deviations.

\section{Results and discussion}

The PCR resulted in the product of $152 \mathrm{bp}$, which was digested with HinfI endonuclease. As a result of this, the following bands were found on the agarose gel: 1 band of $152 \mathrm{bp}$ (genotype $L E P^{\mathrm{T}} L E P^{\mathrm{T}}$ ), two band of 84 and $68 \mathrm{bp}$ (genotype $L E P^{\mathrm{C}} L E P^{\mathrm{C}}$ ), and three bands of 152,84 , and 68 bp (genotype $L E P^{\mathrm{C}} L E P^{\mathrm{T}}$ ).

In the analysed $\mathrm{AI}$ boars herd the allele $L E P^{\mathrm{C}}$ occurred with the frequency 0.287 , whereas the allele $L E P^{\mathrm{T}}$ - with the frequency 0.713 (Table 1). The $L E P^{\mathrm{C}} L E P^{\mathrm{C}}$ leptin genotype occurred with the frequency $0.0926, L E P^{\mathrm{C}} L E P^{\mathrm{T}}$ with frequency 0.3889 , and $L E P^{\mathrm{T}} L E P^{\mathrm{T}}$ genotype with 0.5185 - Table 1.

Table 1

Frequency of genotype and alleles of Lep/HinfI in studied herd of boars (Frequenz der Genotypen und Lep/HinfI Allele in der untersuchten Eberpopulation)

\begin{tabular}{ccc|cc}
\hline $\begin{array}{c}\text { LEP/Hinf } \\
\text { genotype }\end{array}$ & $\mathrm{n}$ & Frequency & Allele & Frequency \\
\hline$L E P^{\mathrm{C}} L E P^{\mathrm{C}}$ & 5 & 0.0926 & $L E P^{\mathrm{C}}$ & 0.2870 \\
$L E P^{\mathrm{C}} L E P^{\mathrm{T}}$ & 21 & 0.3889 & $L E P^{\mathrm{T}}$ & 0.7130 \\
$L E P^{\mathrm{T}} L E P^{\mathrm{T}}$ & 28 & 0.5185 & & 1.0000 \\
\hline Total & 54 & 1.0000 & & \\
\hline
\end{tabular}

In the studied population, no disturbance of genetic equilibrium was found between the observed and the theoretical LEP genotype frequencies, calculated according to the Hardy-Weinberg law $\left(\mathrm{Chi}^{2}=0.134 ; \mathrm{n}^{\prime}=2\right)$.

A similar, also higher frequency of $L E P^{T}$ was observed by STRATIL et al. (1997) who studied the breeds Landrace, Hampshire, Large White, Black Pied Pǒeštice, Pietrain, and Czech Meat Pig; however, the allele was not found in Meishan pigs. A higher frequency of the allele $L E P^{\mathrm{T}}$ was also revealed in Polish Landrace pigs (KULIG et al., 2001).

Considering the mentioned data on leptin gene expression, leptin function, a high degree of the hormone's homology and its receptors location, one may suggest there is an effect of the protein on, among others, reproduction-related traits of pigs or, more specifically, on boar semen characters. Consequently, the studies by BARASH et al. (1996) show that both in males and females of genetically obese ob/ob mice, leptin expressively stimulated gonadal growth and activity. Leptin treatment restored foetal cycle in infertile ob/ob female mice, which were also able to conceive and retain pregnancy (CHEHAB et al., 1996). The fact that leptin influences the gonads probably results in enhanced production of steroid hormones (BARASH et al., 1996). 
The analysis demonstrated that the level of qualitative and quantitative semen traits was significantly influenced by the year $(\mathrm{P} \leq 0.01)$. The following interactions were also found significant: LEP genotype $\mathrm{x}$ year, LEP genotype $\mathrm{x}$ season, and year $\mathrm{x}$ season - Table 2. All these factors were included in the statistical model, which was used to analyse the relationships between the particular LEP genotypes and the traits of the semen.

Table 2

Significance of the influence of factors covered in statistical model on examined characters of boars semen (Signifikanz von Einflussfaktoren auf die untersuchten Spermamerkmale)

\begin{tabular}{|c|c|c|c|c|c|c|}
\hline \multirow[b]{2}{*}{ Character } & \multirow[b]{2}{*}{$\begin{array}{l}\text { LEP } \\
\text { genotype }\end{array}$} & \multirow[b]{2}{*}{ Year } & \multirow[b]{2}{*}{ Season } & \multicolumn{3}{|c|}{ Interaction } \\
\hline & & & & $\begin{array}{c}\text { LEP } \\
\text { Genotype } \\
\text { x Year }\end{array}$ & $\begin{array}{c}\text { LEP } \\
\text { Genotype } \\
\mathrm{x} \text { Season }\end{array}$ & $\begin{array}{l}\text { Year } \mathrm{x} \\
\text { Season }\end{array}$ \\
\hline DF & 2 & 3 & 1 & 5 & 2 & 3 \\
\hline Ejaculate volume & $4.826^{* *}$ & $17.733 * *$ & 0.004 & 1.108 & $5.620^{* *}$ & $5.292 * *$ \\
\hline Sperm concentration & $7.663^{* *}$ & $34.302 * *$ & 0.122 & $3.287^{* *}$ & $4.178^{*}$ & $14.760 * *$ \\
\hline $\begin{array}{l}\text { Normozoospermia } \\
\text { percentage }\end{array}$ & $3.771 *$ & $67.829 * *$ & 1.618 & 0.323 & 1,822 & $10.745^{* *}$ \\
\hline $\begin{array}{l}\text { Number of } \\
\text { normozoospermia } \\
\text { in ejaculate }\end{array}$ & 1.506 & $16.821 * *$ & 0.035 & $2.799 *$ & 2.713 & 0.401 \\
\hline $\begin{array}{l}\text { Number of sperms in } \\
\text { insemination dose }\end{array}$ & $5.551 * *$ & $19.489 * *$ & 0.309 & $10.997 * *$ & 1.733 & 0.457 \\
\hline Boar age & 2.421 & $20.813 * *$ & 1.002 & $9.769^{* *}$ & $10.075 * *$ & $5.103^{* *}$ \\
\hline
\end{tabular}

* - significance of differences at $\mathrm{P} \leq 0,05 ; * *$ significance of differences at $\mathrm{P} \leq 0,01$.

Average ejaculate volume for all the analysed boars was $213.4 \mathrm{~cm}^{3}$ and fell within the range for the boars of this age. The highest mean ejaculate volume was found for the boars with the $L E P^{\mathrm{T}} L E P^{\mathrm{T}}$ genotype $\left(232.9 \mathrm{~cm}^{3}\right)$, while the lowest - for the genotype $L E P^{\mathrm{C}} L E P^{\mathrm{C}}\left(186.2 \mathrm{~cm}^{3}\right)$, and the recorded differences were statistically significant at $\mathrm{P} \leq 0.01$ (Table 3). The mean concentration of spermatozoa was $614.5 \cdot 10^{6} / \mathrm{cm}^{3}$. Higher concentration of spermatozoa was found in the semen of $L E P^{\mathrm{C}} L E P^{\mathrm{C}}$ genotype boars $\left(630.2 \cdot 10^{6} / \mathrm{cm}^{3}\right)$, compared with the mean of the herd and the mean of the $L E P^{\mathrm{C}} L E P^{\mathrm{T}}$ boars $\left(625.4 \cdot 10^{6} / \mathrm{cm}^{3}\right)$, and with $L E P^{\mathrm{T}} L E P^{\mathrm{T}}\left(587.7 \cdot 10^{6} / \mathrm{cm}^{3}\right)$, and the differences were confirmed statistically $(\mathrm{P} \leq 0.01)$ - Table 3 .

The percentage of live sperms was $72.1 \%$, on average, with a significantly higher value $(72.8 \% ; \mathrm{P} \leq 0.05)$ in the semen of boars with $L E P^{\mathrm{T}} L E P^{\mathrm{T}}$ genotype. For the $L E P^{\mathrm{C}} L E P^{\mathrm{C}}$ genotype boars, the percentage of live sperms was $71.0 \%$ (Table 3 ).

The average number of live sperms in an ejaculate was $90.9 \cdot 10^{9}$. The highest number of live sperms was found in the semen collected from the boar $L E P^{\mathrm{C}} L E P^{\mathrm{T}}$ genotype $\left(95.3 \cdot 10^{9}\right)$, whereas the lowest was found for $L E P^{\mathrm{C}} L E P^{\mathrm{C}}$ genotype boars $\left(82.6 \cdot 10^{9}\right)$; the differences being statistically significant (Table 3 ).

A single ejaculate volume allowed obtaining 23.8 insemination doses on average, with 24.8 doses from $L E P^{\mathrm{T}} L E P^{\mathrm{T}}$ boars and 22.1 doses from $L E P^{\mathrm{C}} L E P^{\mathrm{C}}$ boars. The 
differences in the number of insemination doses obtained from different LEP/HinfI genotypes were low and statistically non-significant (Table3).

Table 3

Values of studied semen characters in reference to LEP genotype (Beziehungen untersuchter Spermamerkmale zu den LEP Genotypen)

\begin{tabular}{|c|c|c|c|c|c|c|}
\hline \multirow{2}{*}{ Character } & & \multicolumn{3}{|c|}{$L E P$ genotype } & \multirow{2}{*}{$\mathrm{P}$} & \multirow{2}{*}{ Total } \\
\hline & & $L E P^{\mathrm{C}} L E P^{\mathrm{C}}$ & $L E P^{\mathrm{C}} L E P^{T}$ & $L E P^{\mathrm{T}} L E P^{T}$ & & \\
\hline Number of ejaculates & & 43 & 351 & 621 & - & 1015 \\
\hline Ejaculate volume $\left[\mathrm{cm}^{3}\right]$ & $\begin{array}{c}\text { LSM } \\
\text { SE }\end{array}$ & $\begin{array}{c}186.2 \\
16.2\end{array}$ & $\begin{array}{l}221.0 \\
4.3\end{array}$ & $\begin{array}{c}232.9 \\
4.1\end{array}$ & $* *$ & $\begin{array}{c}213.4 \\
5.7\end{array}$ \\
\hline Sperm concentration $\left[\mathrm{mln} / \mathrm{cm}^{3}\right]$ & $\begin{array}{c}\text { LSM } \\
\text { SE }\end{array}$ & $\begin{array}{l}630.2 \\
27.5\end{array}$ & $\begin{array}{l}625.4 \\
7.3\end{array}$ & $\begin{array}{c}587.7 \\
6.9\end{array}$ & $* *$ & $\begin{array}{c}614.5 \\
9.6\end{array}$ \\
\hline Normozoospermia percentage & $\begin{array}{c}\text { LSM } \\
\text { SE }\end{array}$ & $\begin{array}{c}71.0 \\
0.7\end{array}$ & $\begin{array}{c}72.4 \\
0.2\end{array}$ & $\begin{array}{c}72.8 \\
0.2\end{array}$ & $*$ & $\begin{array}{c}72.1 \\
0.2\end{array}$ \\
\hline $\begin{array}{l}\text { Number of normozoospermia in ejaculate } \\
\text { [bln] }\end{array}$ & $\begin{array}{l}\text { LSM } \\
\text { SE }\end{array}$ & $\begin{array}{c}82.6 \\
7.1\end{array}$ & $\begin{array}{c}95.3 \\
1.9\end{array}$ & $\begin{array}{c}94.8 \\
1.8\end{array}$ & n.s. & $\begin{array}{c}90.9 \\
2.5\end{array}$ \\
\hline Number of sperms in insemination dose [bln] & $\begin{array}{l}\text { LSM } \\
\text { SE }\end{array}$ & $\begin{array}{l}3.7 \\
0.13\end{array}$ & $\begin{array}{c}4.0 \\
0.03\end{array}$ & $\begin{array}{c}3.9 \\
0.03\end{array}$ & $* *$ & $\begin{array}{c}3.8 \\
0.04\end{array}$ \\
\hline Boar age [days] & $\begin{array}{l}\text { LSM } \\
\text { SE }\end{array}$ & $\begin{array}{c}309.2 \\
13.8\end{array}$ & $\begin{array}{c}326.2 \\
3.7\end{array}$ & $\begin{array}{c}316.5 \\
3.5\end{array}$ & n.s. & $\begin{array}{c}317.3 \\
4.8\end{array}$ \\
\hline
\end{tabular}

* significance of difference at $\mathrm{P} \leq 0,05 ; * *$ significance of differences at $\mathrm{P} \leq 0,01 ;$ n.s. - non-significant.

\section{Conclusion}

The studies demonstrated that the boars with the $L E P^{\mathrm{C}} L E P^{\mathrm{C}}$ genotype yielded ejaculates of the lowest volume with the highest sperm concentration, the lowest number and percentage of live sperms, as well as the lowest number of obtained insemination doses.

Therefore, the results suggest that the polymorphism in the leptin gene (LEP/HinfI) may be utilised in the improvement of some reproductive performance traits of boars, such as semen qualitative and quantitative characters. However, despite the fact that the prevalence of $L E P^{\mathrm{C}} L E P^{\mathrm{T}}$ and $L E P^{\mathrm{T}} L E P^{\mathrm{T}}$ genotypes was demonstrated for both percentage and number of live sperms in ejaculate, the results should be verified in further research on a larger number of animals.

\section{References}

BARASH, I.A.; CHEUNG, C.C.; WEIGLE, D.S.; REN, H.; KABIGTING, E.B.; KUIJPER, J.L.; CLIFTON, D.K.; STEINER R.A.:

Leptin is a metabolic signal to the reproductive system. Endocrinology 137 (1996), 3144-3147

BIDWELL, C.A.; JI, S.; FRANK, G.R.; CORNELIUS, S.G.; WILLIS, G.M.; SPURLOCK, M.E.:

Cloning and expression of the porcine obese gene. Animal Biotechnology 8 (1997) 2, 192-206

BLACHE, D.; TELLAM, R.L.; CHAGAS, L.M.; BLACKBERRY, M.A.; VERCOE, P.E.; MARTIN, G.B.:

Level of nutrition affects leptin concentrations in plasma and cerebrospinal fluid in sheep. Journal of Endocrinology 165 (2000), 625-37 
BUCHANAN, F.C.; FITZSIMMONS, C.J.; KESSEL, A.G.; THUE, T.D.; WINKELMAN-SIM, D.C.; SCHMUTZ, S.M.:

Association of a missense mutation in the bovine leptin gene with carcass fat content and leptin mRNA levels. Genetics, selection, evolution. 34 (2002), 105-116

CHEHAB, F.; LIM, M.; LU, R.:

Correction of the sterility defect in homozygous obese female mice by treatment with the human recombinant leptin. Nature Genetics 12 (1996), 318-320

GUAlillO, O.; LAGO, F.; GARCIA, M.; MENÉNDEZ, C.; SEÑAR'IS, C.; SENARIS, R.; CASANUEVA F.F.; DIÉGUEZ, C.:

Prolactin stimulates leptin secretion by rat white adipose tissue. Endocrinology 140 (1999), 5149-5153

HARVEY W.R.:

User's guide for LSMLMW mixed model least-squares and maximum likelihood computer program. Ohio State University, USA, (1987).

HOUSEKNECHT, K.L.; PORTOCARRERO, C.P.:

Leptin and its receptors: regulators of whole-body energy homeostasis. Domestic Animal Endocrinology 15 (1998), 457-475

HOUSEKNECHT, K.L.; PORTOCARRERO, C.P.; JI, S.; LEMENAGER, R.; SPURLOCK, M.E.:

Growth hormone regulates leptin gene expression in bovine adipose tissue: correlation with adipose IGF-1 expression. Journal of Endocrinology 164 (2000), 51-57

JIANG, Z-H.; GIBSON, J.P.:

Genetic polymorphisms in the leptin gene and their association with fatness in four pig breeds. Mammalian Genome 10 (1999), 191-193

KENNES, Y.M.; MURPHY, B.D.; POTHIER, F.; PALIN, M-F.:

Characterization of swine leptin (LEP) polymorphisms and their association with production traits. Animal Genetics 32 (2001), 215-218

KULIG, H.; GRZESIAK, W.; SZATKOWSKA, I.:

Effect of leptin gene polymorphism on growth and carcass traits in pigs. Arch. Tierz., Dummerstorf 44 (2001), 291-296

LIEFERS, S.C.; TE PAS, M.F.W.; VEERKAMP, R.F.; VAN DER LENDE, T.:

Associations between leptin gene polymorphisms and production, live weight, energy balance, feed intake, and fertility in Holstein heifers. Journal of Dairy Science 85 (2002), 1633-1638

LIN, J.; BARB, C.R.; MATTERI, R.L.; KRAELING, R.R.; CHEN, X.; MEINERSMANN, R.J.; RAMPACEK, G.B.:

Long form leptin receptor mRNA expression in the brain, pituitary, and other tissues in the pig. Domestic Animal Endocrinology 19 (2000), 53-61

NEUENSCHWANDER, S.; ROTTENBERGER, G.; MEIJERINK, H.; JORG, H.; STRANZINGER, G.: Partial characterization of porcine obesity gene (OBS) and its localization to chromosome 18 by somatic cell hybrids. Animal Genetics 27 (1996), 275-278

PELLEYMOUNTER, M.A.; CULLEN, M.J.; BAKER, M.B.; HECHT, R.; WINTERS, D.; BOONE, T.; COLLINS F.:

Effects of the obese gene product on body weight regulation in ob/ob mice. Science 269 (1995), 540543

RAMSAY, T.G.; YAN, X.; MORRISON, C.:

The obesity gene in swine: sequence and expression of porcine leptin. Journal of Animal Science 76 (1998), 484-490

RENTSCH, J.; LEVENS, N.; CHIESI, M.:

Recombinant ob-gene product reduces food intake in fasted mice. Biochemical and Biophysical Research Communications 214 (1995), 131-136

SASAKI, S.; CLUTTER, A.C.; POMP, D.:

Assignment of the porcine obese (leptin) gene to Chromosome 18 by linkage analysis of a new PCRbased polymorphism. Mammalian Genome 7 (1996), 471-472

SHIMIZU, H.; SHIMOMURA, Y.; NAKANISHI, Y.; FUTAWATARI, T.; OHTANI, K.; SATO, N.; MORI, M.:

Estrogen increases in vivo leptin production in rats and human subjects. Journal of Endocrinology 154 (1997), 285-292

STRATIL, A.; PEELMAN, L.; VAN POUCKE, M.; ČEPICA, S.:

A HinfI PCR-RFLP at the porcine leptin (LEP) gene. Animal Genetics 28 (1997), 371-372

TARTAGLIA, L.A.:

The Leptin Receptor. The Journal of Biological Chemistry 272 (1997), 6093-6096

XIE, CH.; WEGNER, J.; BROCKMANN, G.A.; KAZALA, CH.; WESELAKE, R.J.; ENDER, K.:

Leptin, a palatability molecule? - A Review. Arch. Tierz., Dummerstorf 42 (1999), 191-199

ZHANG, Y.; PROENCA, R.; MAFFEI, M.; BARONE, M.; LEOPOLD, L.; FRIEDMAN, J.M.: 
Positional cloning of the mouse obese gene and its human homologue. Nature 372 (1994), 425-432 ZWIERZCHOWSKI, L.; OPRZĄDEK, J.; DYMNICKI, E.; DZIERZBICKI, P.:

An association of growth hormone, $\kappa$-casein, $\beta$-lactoglobulin, leptin and Pit-1 loci polymorphism with growth rate and carcass traits in beef cattle. Animal Science Papers and Reports 18 (2000), 107-116

Received: 2002-04-30

Accepted: 2002-12-02

Authors' address

PhD DSc Prof. MAREK KMIEĆ, MSc HANNA KULIG, MSc ANDRZEJ KONIK

Agricultural University of Szczecin

Department of Genetics and Animal Breeding

ul. Doktora Judyma 6

71-460 Szczecin

Poland

E-Mail: M.Kmiec@biot.ar.szczecin.pl 